\title{
多発性硬化症の双子のゲノム解析
}

\section{Twin study surveys genome for cause of multiple sclerosis}

Alla Katsnelson 2010 年 4 月 29 日号 Vol. 464 (1259)

www.nature.com/news/2010/100428/full/4641259a.html

一方のみが多発性硬化症を発症している一卵性双生児のゲノム解析の結果、

発症の違いを説明できる、遺伝的レベル、エピジェネティックレベル、

発現レベルでの差異は見つからなかった。

このほど、一方のみが多発性硬化症 (MS) を発症している女性一卵性双生児のゲノ ムを詳細に比較解析するという、画期的 な研究が行われた。しかし、その結果わ かったのは、たとえ徹底的に遺伝的解析 を行っても明確な答えが得られるとは限 らない、ということだった。

MS は、神経細胞の軸索を包んで絶縁 体の役目をする髄鞘が、炎症により破 壊される疾患である。MSには遺伝的要 因があり、患者の血縁者の発症リスク は高く、一卵性双生児の一方が患者な ら、もう一方の発症リスクは 25 パーセ ント以上になる。ところが、カリフォル ニア大学サンフランシスコ校 (米国) の Sergio Baranzini と米国立ゲノムリソー スセンター（ニューメキシコ州サンタ フェ）の Stephen Kingsmore らが、一 方だけが MS を発症している女性の一卵 性双生児 1 組の全ゲノムの塩基配列を 比較したところ、原因となりそうな遺伝 的差異を発見できなかった。

そこで研究チームは、この一卵性双生 児の免疫細胞と、同じく一方のみ発症し ている別の 2 組の一卵性双生児の免疫 細胞で、エピジェネティクス（遺伝子発 現に影響する後天的な DNA の化学的修 飾）の差異を探した。ところが、いずれ も重要な遺伝子の発現レベルに相違はみ られなかった。この研究結果は、Nature 2010 年 4 月 29 日号に揭載された ${ }^{1}$ 。

研究チームは、1 組しかゲノムの塩基 配列を解読しなかったが、残り 2 組に ついては、発症者と無発症者の塩基配
列で 100 万か所の特異的な一塩基多型 (SNP) を比較し、双子間のゲノムに差 異がないことを確認している。

今回の研究は、徹底的にゲノムを調べ ており、「結果は極めて重要な否定的材 料になります」と、エール大学 (米国コ ネチカット州ニューヘイヴン) の神経学 者 David Hafler は話す。つまり、一卵 性双生児の一方が MS を発症し他方が発 症しない理由を、遺伝学的には明確に説 明できないということである。

疾患の遺伝学研究では、疾患と関連 するSNP を見つけ出すために大規模な 患者集団を調べる場合が多い。しかし、 一方のみが疾患を発症している一卵性 双生児の塩基配列を解読すれば、ゲノ ムをより詳しく比較解析でき、見過ご されていた差異を明らかにできる。一 卵性双生児のゲノムは受精時点では同 じものだが、発生初期に一方に変異が 起こり、もう一方には起こらない場合 があると考えられる。

既に過去の研究で MS の発症リスク と関連するSNPがいくつか見つかって おり、今回の被験者でも全員いくつかの SNPがみられ、ゲノム解析した 1 組の 一卵性双生児では同じ MS 発症リスクを 受け継いでいた、と Kingsmore は説明 する。しかし、遺伝的要因だけでは十分 でなかったようだ。Baranzini によれば、 一方だけが発症した要因の 1 つとして、 $\ulcorner 1$ 人だけが発症に必要な環境要因にさ らされた」ことが考えられるという。

血縁者の全ゲノムを比較解析して疾患

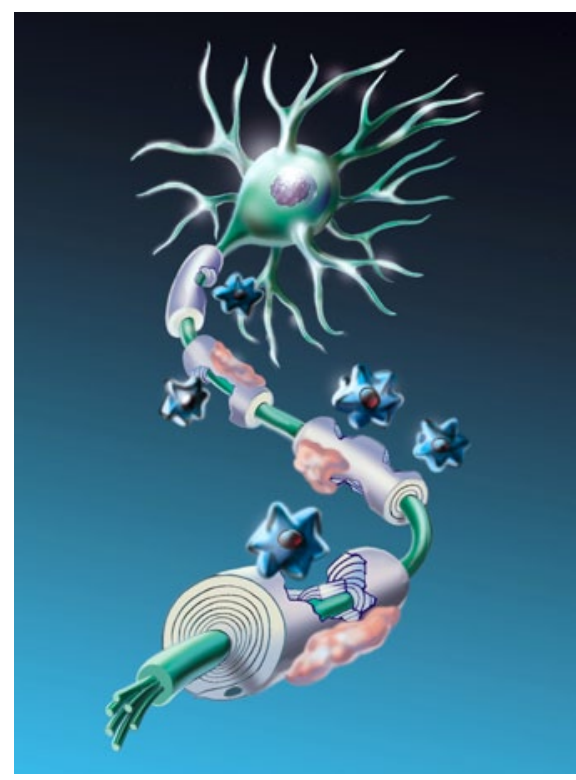

MS 発症の詳しいメカニズムは不明だが、自 己免疫異常が考えられている。

原因の遺伝的変異を見つけることは、新 たな研究領域だと、カリフォルニア大学 ロサンゼルス校 (米国) の神経遺伝学者 Daniel Geschwind は話す。これまでに も、さまざまな疾患の原因と考えられる 遺伝的変異が見つかっている。ただし、 今回の研究は、全ゲノム塩基配列解読 と、エピジェネティクス解析および遺伝 子発現の研究とを初めて統合したという 点で、他とは一線を画している。

しかし、この研究成果から、MS の解 明に直結する手がかりはあまり得られ そうにない。Geschwind はその理由を、 エピジェネティクスや遺伝子発現につい て 3 組の一卵性双生児で調べたのに、完 全なゲノム塩基配列は 1 組しか調べな かったからだ、としている。Kingsmore は、「さらに 10 組以上の双子の塩基配 列を調べれば、もっとはっきりした結果 を出せるでしょうけど」と話し、「免疫 細胞だけでなく、脳組織の DNA 解析に も重点を置くべきでしょう。脳は、一卵 性双生児の発症者と無発症者の間で遺伝 的な差異を示すもう 1 つの部位だと思わ れるからです」と付け加えた。

(翻訳：船田晶子) 